\title{
Proceedings of the second biennial Cleveland Neural Engineering Workshop 2013
}

\author{
Kim Anderson 1,2, Abidemi Ajiboye ${ }^{2,3}$, Timothy Denison ${ }^{4}$, Jennifer French ${ }^{5}$, Kenneth Gustafson ${ }^{2,3}$, Kevin Kilgore ${ }^{2,6}$, \\ Naomi Kleitman ${ }^{7}$, Audrey Kusiak ${ }^{8}$, Brian Litt ${ }^{9}$, Megan Moynahan ${ }^{10}$, Eric Perreault ${ }^{11}$, Douglas Weber ${ }^{12}$, \\ Justin Williams ${ }^{13}$ and Dustin Tyler ${ }^{2,3^{*}}$ iD
}

\begin{abstract}
The Cleveland Neural Engineering Workshop (NEW) is a biennial meeting started in 2011 as an "unconference" to bring together leaders in the neural engineering and related fields. Since the first iteration of the meeting, NEW has evolved from "just getting together" to a more important purpose of creating, reviewing, and promoting a uniform strategic roadmap for the field. The purpose of this short report, as well as the companion 2015 and 2017 reports, is to provide a historical record of this meeting and the evolution of the roadmap. These reports more importantly establish a baseline for the next meeting to be held in June, 2019. The second Neural Engineering Workshop (NEW) was held in June 2013. The two-day workshop was hosted by the Cleveland Advanced Platform for Technology National Veterans Affairs Center, the Functional Electrical Stimulation National Veterans Affairs Center, and the Case Western Reserve University in Cleveland, Ohio. Participants identified seven areas of future focus in the field of neural engineering: active communications with users, advocacy (regulatory), network building (clinical practice), case studies (clinical and technical), early industrial feedback, value chain resources, engagement, and advocacy (funding). This proceedings document summarizes the meeting outcome.
\end{abstract}

Keywords: Neural, Engineering, Strategy, Infrastructure, Advocacy, Rehabilitation, Nervous system

\section{Introduction}

The goal was to bring together the neural engineering stakeholders with the specific purpose of developing a strategic plan, an infrastructure plan and best practices for the community. In June 2013 a select group of individuals were invited to participate in the Cleveland Neural Engineering Workshop (NEW). Individuals were selected based on their knowledge, contributions and advocacy to their respective fields. Action committees were comprised of 9-15 members. Each action committee was led by a provocateur(s) and included at least one executive committee member as a discussant (Table 1). Discussions from the members in attendance (Table 2) resulted in eight action items that the workshop

\footnotetext{
* Correspondence: dustin.tyler@case.edu

${ }^{2}$ Cleveland VA Medical Center, Cleveland, OH, USA

${ }^{3}$ Dept of Biomedical Engineering Case Western Reserve Univ, Cleveland, $\mathrm{OH}$, USA

Full list of author information is available at the end of the article
}

identified as important to progress in neural engineering: active communications with users, advocacy (regulatory), network building (clinical practice), case studies (clinical and technical), early industrial feedback, value chain resources, engagement, and advocacy (funding). These items grew from initial discussion in the 2011 meeting (Table 3) and are summarized below.

\section{Active communications with users}

Members of the workshop voiced concerns regarding communication between scientists and end-users. Scientists do not fully understand end-users' needs (the input specifications), while end-users are not sufficiently aware of available technologies. There is insufficient communication between the end-user and the research enterprise. Therefore, improved bidirectional communication with the end-user is needed. Improved communication methods, consumer education programs, and common collective messaging might achieve this. 
Table 1 ClevelandNEW 2013 session summary. The table lists the eight planned sessions along with the last name(s) of the provocateur(s) and discussant assigned to lead those sessions

\begin{tabular}{lll}
\hline Session Title & Provocateur(s) & Discussant \\
\hline Introduction & Tyler & Gustafson/Tyler \\
User/Consumer & French & Anderson \\
Regulatory/Reimbursement & Moynahan & Ajiboye \\
Clinical Practice & Litt & Weber \\
Technology/Innovation & Kilgore/Loeb & Perreault \\
Industry Translation & Denison & Williams \\
Funding & Kleitman/Kusiak & Gustafson \\
Summary & Tyler & Gustafson/Tyler \\
\hline
\end{tabular}

\section{Regulatory advocacy and reimbursement}

The research community is insufficiently aware of Food and Drug Administration (FDA) regulations, upcoming changes to regulations, and the impact regulations have on research. Current regulations are predominately designed for commercial interests to achieve marketing approval. Testing requirements are suboptimal for early-phase, academic research. Moreover, increased requirements are becoming prohibitive to academic clinical research. As single voices, researchers have limited capability to change or affect the FDA. Therefore, stakeholders must join together to voice their concerns, as well as partner with larger interests in order to address the needs of the community.

\section{Network building for clinical practice}

Members of the workshop recognized the complex challenges faced by clinicians when incorporating neural engineering into daily clinical practice. It was also recognized that inclusion of clinical colleagues in the development of neural technology would result in mutual benefits to scientists and clinicians. Building networks of clinicians interested in neural engineering may be an efficient and effective method to bridge the current communications gap. Clinician education is also an important step in building these networks and ultimately moving neural engineering into mainstream clinical practice. Therefore, there is a need for development of continuing education courses designed to train clinicians in neural engineering.

\section{Clinical and technical case studies}

There is a paucity of accurate and objective sources regarding success or failure or neural engineering technology.

Table 2 List of ClevelandNEW 2013 workshop participants

\begin{tabular}{|c|c|c|c|}
\hline Name & Institution (in 2013) & Name & Institution (in 2013) \\
\hline Ajiboye, Bolu & Case Western Res Univ & Loeb, Gerald & Univ of S California \\
\hline Anderson, Kimberly & Univ of Miami & Marasco, Paul & Louis Stokes Cle VA \\
\hline Bensmaia, Sliman & Univ of Chicago & Mclntyre, Cameron & Case Western Res Univ \\
\hline Bourbeau, Dennis & Case Western Res Univ & Merrill, Dan & Ripple, LLC \\
\hline Brill, Natalie & Case Western Res Univ & Miller, Jonathan & Case Western Res Univ \\
\hline Brose, Steve & Louis Stokes Cle VA & Miller, Lee & Northwestern Univ \\
\hline Capadona, Jeffrey & Case Western Res Univ & Mohseni, Pedram & Case Western Res Univ \\
\hline Cullen, D. Kacy & Univ of Pennsylvania & Moynahan, Megan & Inst for Func Recovery \\
\hline Denison, Timothy & Medtronic & Muthuswamy, Jit & Arizona State Univ \\
\hline Durand, Dominique & Case Western Res Univ & Otto, Kevin & Purdue Univ \\
\hline Fisher, Lee & Case Western Res Univ & Peckham, Hunter & Case Western Res Univ \\
\hline French, Jennifer & Neurotech Network & Perreault, Eric & Northwestern Univ \\
\hline Gaunt, Robert & Univ of Pittsburgh & Polacek, Laura & MetroHealth Med Cntr \\
\hline Guillory, Shane & Ripple, LLC & Schiefer, Matt & CWRU \& Cle VA \\
\hline Gustafson, Kenneth & Case Western Res Univ & Sensinger, Jon & Rehab Inst of Chicago \\
\hline Hess, Allison & CWRU \& Cle VA & Solanki, Swarna & Case Western Res Univ \\
\hline Johnson, Matthew & Univ of Minnesota & Triolo, Ronald & CWRU \& Cle VA \\
\hline Keith, Michael W. & MetroHealth Med Cntr & Tyler, Dustin & CWRU \& Cle VA \\
\hline Kilgore, Kevin & MetroHealth Med Cntr & Wagenaar, Joost & Univ of Pennsylvania \\
\hline Kirsch, Bob & CWRU \& Cle VA & Weber, Douglas & Univ of Pittsburgh \\
\hline Kleitman, Naomi & Craig H. Neilsen Found & Williams, Justin & Univ of Wisconsin \\
\hline Kusiak, Audrey & Dept of Veterans Affairs & Williams, Matt & Louis Stokes Cle VA \\
\hline Litt, Brian & Univ of Pennsylvania & Zorman, Christian & Case Western Res Univ \\
\hline
\end{tabular}


Table 3 List of ClevelandNEW 2011 workshop participants

\begin{tabular}{|c|c|c|c|}
\hline Name & Institution (in 2011) & Name & Institution (in 2011) \\
\hline Ajiboye, Bolu & Cleveland FES Center & Lavik, Erin & Case Western Res Univ \\
\hline Batista, Aaron & Univ of Pittsburgh & Lujan, Luis & Cleveland Clinic \\
\hline Bikson, Marom & City Univ of New York & McIntyre, Cameron & Cleveland Clinic \\
\hline Bourbeau, Dennis & Univ of Pittsburgh & Mohseni, Pedram & Case Western Res Univ \\
\hline Bretl, Timothy & U. Illinois at U-C & Moran, Dan & Washington Univ \\
\hline Brose, Steven & Cleveland FES Center & Murphey, Todd & Northwestern Univ \\
\hline Bruns, Tim & Univ of Pittsburgh & Naqvi, Hassan & Cleveland Clinic \\
\hline Butson, Christopher & Med Col of Wisconsin & Otto, Kevin & Purdue Univ \\
\hline Capadona, Jeffrey & Case Western Res Univ & Peckham, P. Hunter & Cleveland FES Center \\
\hline Carney, Paul & Univ of Florida & Perreault, Eric & Northwestern Univ \\
\hline Chestek, Cynthia & Stanford University & Pinault, Gilles & Louis Stokes Clev VA \\
\hline Cui, Xinyan & Univ of Pittsburgh & Putnam, David & Cornell Univ \\
\hline Dorval, Chuck & Univ of Utah & Sachs, Nich & Northwestern Univ \\
\hline Dukelow, Sean & Univ of Calgary & Schiefer, Matthew & Case Western Res Univ \\
\hline Fridman, Gene & Johns Hopkins Univ & Shenoy, Krishna & Stanford Univ \\
\hline Gaunt, Robert & Univ of Pittsburgh & Shoham, Shy & Technion \\
\hline Gilbert, Ryan & Rensselaer Polytech Inst & Sloan, Andrew & University Hospitals \\
\hline Gliha, Karen & $\mathrm{n} / \mathrm{a}$ & Slutzky, Marc & Northwestern Univ \\
\hline Gliha, Tom & $\mathrm{n} / \mathrm{a}$ & Stegemann, Jan & Univ of Michigan \\
\hline Gustafson, Kenneth & CWRU \& Cle VAMC & Sutter, Maria & $\mathrm{n} / \mathrm{a}$ \\
\hline Hasenwinkel, Julie & Syracuse Univ & Taylor, Dawn & Clev Clinic \& Cle VA \\
\hline Helms-Tillery, Stephen & Arizona State Univ & Triolo, Ronald & CWRU \& Cle VA \\
\hline Hess, Allison & Case Western Res Univ & Tyler, Dustin & CWRU \& Cle VA \\
\hline Ho, Chester & Univ of Calgary & Ustin, Jeffrey & MetroHealth Med Cntr \\
\hline Hoyen, Harry & MetroHealth Med Cntr & Wang, Wei & Univ of Pittsburgh \\
\hline Jarosiewicz, Beata & Brown Univ & Weber, Doug & Univ of Pittsburgh \\
\hline Kelly, Clay & Louis Stokes Cle VA & Wheeler, Don & $\mathrm{n} / \mathrm{a}$ \\
\hline Kirsch, Robert & Cleveland FES Center & Yu, Byron & Carnegie Mellon Univ \\
\hline Kusiak, Audrey & Dept of Veterans Affairs & Zorman, Christian & Case Western Res Univ \\
\hline
\end{tabular}

This has led to dissemination of misinformation to stakeholders.

Similarly, there is a lack of a "best practices collection" for clinicians and researchers. This has led to individual reallocation of time and resources to solve challenges that may already have been addressed with success by others in the field. Therefore, there is a need for development of a clinical cases data and resource module that is user-friendly and scalable for the future.

\section{Early industrial feedback}

The workshop members agreed, "We have a classical problem of building hammers and looking for nails." The pathway from technology to implementation could be expedited if a feedback mechanism with industry was available early in the technology development process.
Therefore, the community must develop best practices and create opportunities to engage in industrial feedback early on in the technology development life cycle.

\section{Value chain resources}

Corporations employ models of technology assessment a technology value chain. The value chains for different companies are different. Having insight into the value chains and pathways may help optimize the research and design process. Therefore, the goal is to develop a resource of this information available to the community.

\section{Engagement}

There are significant challenges to securing funding in this space. One reason may be the lack of involvement by stakeholders. General funding development and the 
subsequent review process for awards would greatly benefit from improved engagement by researchers and leaders in the field. Currently, community leadership does not sufficiently engage in professional obligations such as review panels, advocacy in congress, and other national service-related activity. Therefore, the goal of this action committee is to engage in support and service.

\section{Advocacy for funding}

Currently, there are assumptions and misinformation regarding funding, as well as lack of clarity by the research community, as to the appropriate funding mechanisms for their work. Ideally, a resource would be generated that would supply or connect the community to: funding resource road maps, information graphics, and other guides that are or may become available. This one-stop-shop of funding information should also be used to collect user feedback to assist in identifying funding mechanism appropriateness and utilization. In addition to appropriately allocating funding, it is of utmost importance that the research community provides information and justification for additional investments in new opportunities. Therefore, this action item will support consumer advocacy, veteran services organizations, Congress and appropriate lobbying organizations.

\section{Abbreviations}

FDA: Food and Drug Administration; NEW: Neural Engineering Workshop

\section{Funding}

U.S. Department of Veterans Affairs. Award Number: Cleveland FES Center. Recipient: Dustin J. Tyler, PhD.

U.S. Department of Veterans Affairs. Award Number: Cleveland APT Center. Recipient: Dustin J. Tyler, PhD.

National Institute of Child Health and Human Development. Award Number: R13HD078115. Recipient: Kenneth Gustafson, PhD.

\section{Authors' contributions}

KA, BA, TD, JF, KG, KK, NK, AK, BL, MM, EP, DW, JW, and DT wrote the paper. All authors read and approved the final manuscript.

\section{Ethics approval and consent to participate}

Not applicable.

Consent for publication

Not applicable.

\section{Competing interests}

The authors declare that they have no competing interest.

\section{Publisher's Note}

Springer Nature remains neutral with regard to jurisdictional claims in published maps and institutional affiliations.

\section{Author details}

${ }^{1}$ Dept of Physical Medicine and Rehabilitation, Case Western Reserve Univ, Cleveland, OH, USA. ${ }^{2}$ Cleveland VA Medical Center, Cleveland, $\mathrm{OH}, \mathrm{USA}$. ${ }^{3}$ Dept of Biomedical Engineering Case Western Reserve Univ, Cleveland, $\mathrm{OH}$, USA. ${ }^{4}$ Nuffeild Dept of Clinical Neurosciences Oxford University, Oxford, UK. ${ }^{5}$ Neurotech Reports, San Francisco, CA, USA. ${ }^{6}$ Dept of Orthopaedics MetroHealth Medical Center, Cleveland, OH, USA. ${ }^{7}$ Craig H Neilsen Foundation, Encino, CA, USA. ${ }^{8}$ Rehabilitation Research and Development Department of Veterans Affairs, Washington, DC, USA. 'Dept of Neurology and Dept of Bioengineering Univ of Pennsylvania, Philadelphia, PA, USA.

${ }^{10}$ Institute for Functional Recovery, Cleveland, OH, USA. ${ }^{11}$ Dept of Biomedical Engineering Northwesten University, Chicago, IL, USA. ${ }^{12}$ Dept of Bio Engineering University of Pittsburgh, Pittsburgh, PA, USA. ${ }^{13}$ Dept of Biomedical Engineering Univ of Wisconsin-Madison, Madison, WI, USA.

Received: 19 September 2018 Accepted: 8 October 2018

Published online: 05 December 2018
Ready to submit your research? Choose BMC and benefit from:

- fast, convenient online submission

- thorough peer review by experienced researchers in your field

- rapid publication on acceptance

- support for research data, including large and complex data types

- gold Open Access which fosters wider collaboration and increased citations

- maximum visibility for your research: over $100 \mathrm{M}$ website views per year

At BMC, research is always in progress.

Learn more biomedcentral.com/submissions 